\title{
Understanding the climate impacts on decadal vegetation change in northern Alaska ${ }^{1}$
}

\author{
Jacob A. Harris, Robert D. Hollister, Timothy F. Botting, Craig E. Tweedie, \\ Katlyn R. Betway, Jeremy L. May, Robert T.S. Barrett, Jenny A. Leibig, \\ Hana L. Christoffersen, Sergio A. Vargas, Mariana Orejel, and Tabatha L. Fuson
}

\begin{abstract}
The Arctic is experiencing rapid climate change. This research documents changes to tundra vegetation near Atqasuk and Utqiagivik, Alaska. At each location, 30 plots were sampled annually from 2010 to 2019 using a point frame. For every encounter, we recorded the height and classified it into eight groupings (deciduous shrubs, evergreen shrubs, forbs, graminoids, bryophytes, lichens, litter, and standing dead vegetation); for vascular plants we also identified the species. We found an increase in plant stature and cover over time, consistent with regional warming. Graminoid cover and height increased at both sites, with a 5-fold increase in cover in Atqasuk. At Atqasuk, the cover and height of shrubs and forbs increased. Species diversity decreased at both the sites. Year was generally the strongest predictor of vegetation change, suggesting a cumulative change over time; however, soil moisture and soil temperature were also predictors of vegetation change. We anticipate that plants in the region will continue to grow taller as the region warms, resulting in greater plant cover, especially of graminoids and shrubs. The increase in plant cover and accumulation of litter may negatively impact non-vascular plants. Continued changes in community structure will impact energy balance and carbon cycling and may have regional and global consequences.

Key words: tundra, vegetation change, plant height, climate change, ITEX.

Résumé : L’Arctique connaît un changement climatique rapide. Cette recherche documente les changements de la végétation de la toundra près d'Atqasuk et d'Utqiagivik, en Alaska. À chaque emplacement, 30 parcelles ont été échantillonnées chaque année de 2010 à 2019 en utilisant un cadre de criblage systématique. Pour chaque rencontre, les auteurs ont enregistré la hauteur et l'ont classée en huit groupes (arbustes à feuilles caduques, arbustes à feuilles persistantes, herbes non graminéennes, graminoïdes, bryophytes, lichens, litière et végétation morte sur pied); pour les plantes vasculaires, ils ont aussi identifié l'espèce. Ils ont constaté une augmentation de la hauteur et du couvert des végétaux au fil du temps,
\end{abstract}

\footnotetext{
Received 4 November 2020. Accepted 12 May 2021.

J.A. Harris, R.D. Hollister, K.R. Betway, J.A. Leibig, and H.L. Christoffersen. Department of Biological Sciences, Grand Valley State University, 1 Campus Drive, Allendale, MI 49401, USA.

T.F. Botting. Department of Biological Sciences, Grand Valley State University, 1 Campus Drive, Allendale, MI 49401, USA; USDA Natural Resources Conservation Service, 2187 N Stevens Street \#A, Rhinelander, WI 54501, USA.

C.E. Tweedie, S.A. Vargas, M. Orejel, and T.L. Fuson. Department of Biological Sciences, The University of Texas at El Paso, 500 W University Avenue, El Paso, TX 79968, USA.

J.L. May. Department of Biological Sciences, Grand Valley State University, 1 Campus Drive, Allendale, MI 49401, USA; Department of Biological Sciences, Florida International University, 11200 SW 8th Street, Miami, FL 33199, USA.

R.T.S. Barrett. Department of Biological Sciences, Grand Valley State University, 1 Campus Drive, Allendale, MI 49401, USA; Kent Innovation High School, 1655 E Beltline Avenue NE, Grand Rapids, MI 49525, USA.

Corresponding author: Jacob A. Harris (email: harrisj6@mail.gvsu.edu).

${ }^{1}$ This paper is part of a Special Issue entitled: Impacts of climate change on tundra ecosystems: Three decades of results from the International Tundra Experiment (ITEX).

(C) 2021 The Author(s). This work is licensed under a Creative Attribution 4.0 International License (CC BY 4.0), which permits unrestricted use, distribution, and reproduction in any medium, provided the original author(s) and source are credited.
} 
ce qui correspond au réchauffement régional. Le couvert et la hauteur des graminées augmentaient sur les deux sites, avec un couvert cinq fois plus important à Atqasuk. À Atqasuk, le couvert et la hauteur des arbustes et des herbes augmentaient. La diversité des espèces diminuait sur les deux sites. L'année était généralement le prédicteur le plus fort du changement de végétation, ce qui suggère un changement cumulatif au fil du temps ; toutefois, l'humidité et la température du sol étaient également des prédicteurs du changement de végétation. Les auteurs prévoient que les plantes de la région continueront de croître en hauteur à mesure du réchauffement de la région, ce qui entraînera un plus grand couvert végétal, en particulier des graminoïdes et des arbustes. L'augmentation du couvert végétal et l'accumulation de la litière peuvent avoir un impact négatif sur les plantes non vasculaires. Les changements continus de la structure de la communauté auront un impact sur le bilan énergétique et le cycle du carbone et pourraient avoir des conséquences régionales et mondiales. [Traduit par la Rédaction]

Mots-clés : toundra, changement de végétation, hauteur des plantes, changement climatique, ITEX.

\section{Introduction}

Anthropogenic climate change has been documented for over a century, although the intensity of change has increased over the past few decades, global temperatures may increase by as much as approximately $5{ }^{\circ} \mathrm{C}$ over the next 100 years (IPCC 2018). High-latitude regions may expect at least twice the rate of warming in lower-latitude regions (AMAP 2019). The observed warming trend is of interest because the Arctic region is particularly sensitive to climate change and, in part, responsible for balancing the global atmospheric carbon budget and regulating the energy balance of the Earth (Chapin et al. 2000). Vegetation responses to climate change are a focal point of research because vegetative communities are determined, at least partially, by regional climate. Generally, Arctic plants are limited by the cold conditions in which they are found (cold and freezing temperatures, low nutrient availability) (Chapin 1983; Chapin et al. 1995). Therefore, plants tend to respond to warming with enhanced growth and life cycle progression (Arft et al. 1999; Hollister and Flaherty 2010) and increased reproductive success (Myers-Smith et al. 2011), although there is evidence that this effect may wane with time (Kremers et al. 2015). An extension of the growing season, warmed air temperatures, and hastened rate of snowmelt are largely responsible for this enhanced growth and life cycle progression (Walther 2010; Oberbauer et al. 2013). Warming of the Arctic may cause increased rates of soil organic matter decomposition and enhanced greenhouse gas emissions, leading to an increase and acceleration of warming. The positive feedback loop of increasing greenhouse gas emissions has global consequences (Rustad et al. 2001; Melillo et al. 2002; Davidson and Janssens 2006). The permafrost regions of the Northern Hemisphere hold approximately twice as much carbon as is currently present in the atmosphere (Zimov et al. 2006; Tarnocai et al. 2009). It is likely that $5 \%$ to $15 \%$ of this carbon is vulnerable to decomposition and entering the atmosphere within this century (Schuur et al. 2015).

It is difficult to forecast the vegetation response to warming because changes in environmental conditions, in addition to air temperature, may significantly alter the Arctic vegetation. Soil moisture is a major controlling factor of the species composition for any given geographic area; this is equally true in tundra vegetation (Chapin et al. 1996; Phoenix et al. 2001; Gamon et al. 2013). Soil moisture and soil temperature are limiting factors for the decomposition rates of plant litter (Hobbie 1996; Shaver et al. 2006), which subsequently affects carbon and nitrogen cycling within a community. Increases in labile phosphorous via soil organic matter decomposition have been shown to increase soil respiration rates with increases in soil nitrogen (Liu et al. 2021). Soil temperature, which can vary 
significantly from air temperature, is a known influencer of plant phenological progression (Oberbauer et al. 1998), overall nutrient availability (Melillo et al. 2002), and net primary productivity (Natali et al. 2012). The growing season soil thaw depth is another important abiotic factor affecting plant communities, as it directly impacts soil moisture and nutrient availability, which in turn influences community growth rates and composition (Anisimov and Reneva 2006; Schuur et al. 2007).

Plants are a critical component of terrestrial ecosystems. As net primary producers, they provide bottom-up control for other trophic levels of the entire ecosystem. Thus, the characteristics of a plant community influence herbivory patterns via variations in forage quality or quantity (Augustine and McNaughton 1998; Joly et al. 2009) and energetic exchanges within ecosystems (Post and Forchhammer 2008), which ultimately affect animal community composition (Orians and Wittenberger 1991; Rettie and Messier 2000). Additionally, plant species differ in their impacts on nutrient cycling, resource partitioning, and ultimately soil nutrient dynamics, which have ecosystem-wide implications (Vinton and Burke 1995).

Long-term studies of Arctic plant communities and their responses to environmental variability are needed to document and better understand the drivers of tundra vegetation change, in light of extended growing seasons, prolonged exposure to summer temperatures, and fluctuations in soil moisture and soil thaw depth (Blok et al. 2011). For example, significant increases in plant cover have been attributed to regional warming at many locations across the Arctic (Hudson and Henry 2009; Jorgenson et al. 2015; Myers-Smith et al. 2019). Documented changes also include advances in tree lines (Harsch et al. 2009; MyersSmith and Hik 2018) and shrubification of existing tundra (Forbes et al. 2010; Hallinger et al. 2010; Elmendorf et al. 2012; Grigoriev et al. 2020). Detailed information on plant cover and height provides the building blocks necessary for understanding the changes in the competitive interactions between species and functional groups, and enable better prediction of changes in canopy structure and its implications on energy balance and habitat for migratory birds or yearlong resident mammals, and arthropods (Post and Forchhammer 2008; Gilg et al. 2009; Gauthier et al. 2013; Asmus et al. 2018).

This study examines a decade of vegetation change at two locations in the northernmost Alaska in relation to regional warming and other environmental factors. The findings will be of value to researchers working in both low and coastal Arctic environments. The following specific questions were addressed:

1. How have plant cover, height, and diversity changed over time?

2. What are the drivers of vegetation change?

3. Are the drivers of vegetation change consistent across locations?

\section{Materials and methods}

Study sites

Two study sites in northern Alaska were sampled: one near the Arctic Ocean coast at Utqiagivik (formerly Barrow), Alaska $\left(71^{\circ} 19^{\prime} \mathrm{N}, 156^{\circ} 36^{\prime} \mathrm{W}\right)$, and the other approximately $100 \mathrm{~km}$ south of Atqasuk, Alaska $\left(70^{\circ} 27^{\prime} \mathrm{N}, 157^{\circ} 24^{\prime} \mathrm{W}\right)$ (Fig. 1). Utqiagivik was defined as Biozone $C$ and Atqasuk as Biozone D by Raynolds et al. (2006). Utqiagvik and Atqasuk are both in region W1 (sedge/grass, moss wetland) on the circumpolar vegetation map (CAVM Team 2003). At each location, long-term $1 \mathrm{~m}^{2}$ plots were laid out in a $1 \mathrm{~km}^{2}$ grid with approximately 100 plots spaced $100 \mathrm{~m}$ apart, which was originally established to monitor long-term terrestrial ecosystem change by the Arctic System Science Program, and is sometimes referred to as the ARCSS grid, which is how they will be referenced in this manuscript. The grids are also used by the Circum-Arctic Active Layer Monitoring 
Fig. 1. Locations of Atqasuk (red) and Utqiagvik (blue) on the North Slope of Alaska (Google Earth 2020).

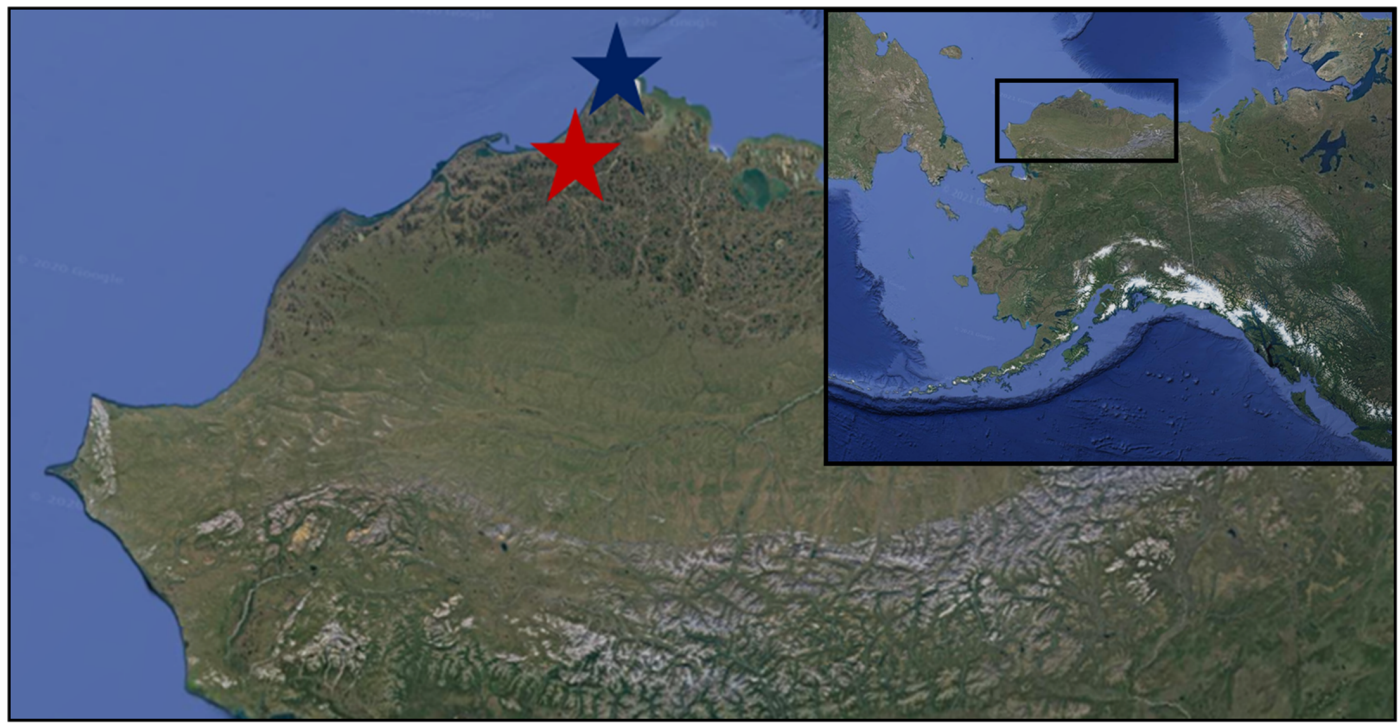

Program and are often referred to as CALM grids (Hinkel and Nelson 2003). Both grids have a subset of 30 plots that are sampled annually, which is the focus of this study. Habitats within the Atqasuk grid include dry, raised ridges, moist tussock tundra, saturated meadows and ponds, and ice-wedge polygons. Habitats within the Utqiagivik grid range from dry, raised ridges to saturated meadows and ponds, and also include ice-wedge polygons. A small amount of vehicle disturbance occurs from winter snow machines and the rare but more impactful occurrence of summer ATV traffic. No vehicles directly impacted any plots during the sampling period; however, there was minor foot disturbance near the plots due to repeated sampling, which was more pronounced in the watersaturated areas. The plots described here are adjacent to, but not part of, the warming experiments at the International Tundra Experiment (ITEX) sites (Hollister et al. 2006; Hollister et al. 2015).

\section{Climate monitoring}

Weather stations were installed within the ARCSS grids at both Atqasuk and Utqiagivik in the 1990s as part of the International Tundra Experiment sites. Air temperature $\left({ }^{\circ} \mathrm{C}\right)$ was measured at a height of $2 \mathrm{~m}$ from the ground using a model 107 temperature probe (Campbell Scientific Inc., Logan, Utah, USA). Precipitation $(\mathrm{cm})$ was measured with a 35-cm TE525 tipping bucket rain gauge (Campbell Scientific Inc.). These data were logged every hour using a CR10X datalogger (Campbell Scientific Inc.). Further details regarding climate monitoring at these sites are available in Hollister et al. (2006). Thawing degree day values (the average of temperatures above $0{ }^{\circ} \mathrm{C}$, summed daily) were calculated from the temperature measurements obtained from either weather station. Plot level environmental variables, collected every 1-2 weeks throughout each summer, included soil moisture as unitless volumetric water content measured with a FieldScout TDR 300, which records soil moisture as a single value at a depth of $10 \mathrm{~cm}$, soil temperature $\left({ }^{\circ} \mathrm{C}\right)$ obtained by a Weber 6492 thermometer at a depth of $10 \mathrm{~cm}$, and soil thaw depth $(\mathrm{cm})$ with a graduated steel probe. All values used in this analysis were collected between June 15 and July 15 to examine the relationship between vegetation and abiotic factors occurring during the 
sampling field season. Measurements were typically taken in the afternoon. Soil temperatures were not collected at Utqiagvik in 2010 and Atqasuk in 2015, and soil thaw depth was not collected at Atqasuk in 2013.

\section{Vegetation sampling}

Plots were sampled annually from 2010 to 2019, excluding 2011. The method used for vegetation sampling was a nondestructive point frame, as described in the ITEX manual (Molau and Mǿlgarrd 1996). Point framing occurred from early July to mid-August. Each individual plot was sampled within a 14 day-of-the-year range across years to minimize differences in phenological progression between years. A $75 \mathrm{~cm}^{2} 100$-point frame with point coordinates spaced $7.5 \mathrm{~cm}$ apart was raised on aluminum rods to just above the observed canopy height. Each plot had permanent markers affixed to the ground that were used to align the frame to attempt to measure the exact same points at each yearly sampling. Each point was measured with a graduated rod to assess plant identity, living status, and position in the canopy. All of the plants contacted by the rod were counted as occupying that coordinate, with no set maximum number of occupants per coordinate point, which is a modification of the method described by Walker (1996) because it included all encounters (May and Hollister 2012). Vascular plants were identified to species and assigned to functional groups. Nonvascular plant encounters were grouped by functional group. The following functional groups were used in this analysis: deciduous shrub; evergreen shrub; forbs; graminoids; bryophytes; lichens; leaf litter; and standing dead vegetation. Nonvascular plants were grouped as follows: acrocarpous mosses; pleurocarpous mosses; crustose lichens; foliolose lichens; and fruticose lichens.

Cover was calculated as the sum of all encounters in a plot. Species height $(\mathrm{cm})$ was calculated as the height of the encounter relative to the ground. For the height analysis, we used the maximum height of each taxon (functional group or species) per plot.

\section{Data analysis}

All statistical analyses were performed using R software for statistical computing v. 3.6.2 ( $\mathrm{R}$ Core Team 2019). When calculating cover for each plot, all 30 plots were used regardless of whether a functional group or species was encountered in the plot for a given year (i.e., zeros were entered into the resulting database). Species visibly present in a plot but not encountered during point-framing were given a value of 0.1 for the year in which they were present. When calculating height metrics, only plots in which a functional group or species occurred for all nine sampling years were included in the analysis; thus, a variable number of plots were used for each functional group or species (i.e., the sample size varied between taxa based on frequency). Nonvascular plants were omitted from height analysis. Only taxa that had over 200 encounters throughout all sampling years were included in the cover and height analyses. For a complete list of species represented by functional groups (see the Supplementary data, File S1, Table $S 1^{2}$ ). To calculate diversity metrics, only vascular species that occurred in five or more plots for a single year were used, to minimize inconsistencies in the sampling of very rare species. "Alpha diversity" was calculated as the total number of vascular plant species that occurred in a given plot. "Gamma diversity" was calculated as the total number of vascular plant species that occurred throughout the site (all 30 plots) in a given year. "Beta diversity" was calculated by dividing gamma diversity by alpha diversity. Shannon's index and Pielou's evenness diversity indices were calculated using the R package "vegan" (Oksanen et al. 2019).

\footnotetext{
${ }^{2}$ Supplementary data are available with the article at https://doi.org/10.1139/as-2020-0050.
} 
The distribution of datasets was checked using the Shapiro-Wilk normality test. If a dataset did not approximate a normal distribution after data transformation attempts, then nonparametric tests were used. For cover analyses, a Bayesian Poisson regression was used to model the relationship between plant cover and abiotic factors, including time, and to model the relationships between the cover of functional groups used while accounting for the non-normality of the dataset due to the presence of many zeros. The packages "rstan" (Stan Development Team 2020) and "brms" (Bürkner 2018) were used to enable the Bayesian analyses. A Poisson distribution was assumed because of the count-based nature of the dataset. Bayesian regression models were considered significant if the credible intervals for the model did not overlap zero. For Bayesian regression, we chose the widely applicable information criterion (WAIC) as a means of comparing models that share the same regressed variable. For height analyses, a general linear mixed model was used to model the relationships between the height of functional groups and abiotic variables using the package "lme4" (Bates et al. 2015). Marginal $r^{2}$ was obtained from a function within the package "MuMIn" (Barton 2019). Diversity indices were also modeled using linear mixed models. Abiotic trends over time were measured using Spearman's rho test.

\section{Results}

\section{Abiotic factors}

At Atqasuk, all of the abiotic factors we measured were positively correlated with year (Supplementary data, File S1, Tables S1 and S2 ${ }^{2}$ ). At Utqiagvik, the abiotic factors positively correlated with year were average air temperature, maximum air temperature, thawing degree day sums, maximum soil temperature, sum of precipitation, and average soil moisture (Fig. 2; Supplementary data, File S1, Tables S1 and S2 ${ }^{2}$ ). The data used may be found in the Supplementary data (File $S 2^{2}$ ).

\section{Vegetation cover}

At Atqasuk, the cover of all vascular plant functional groups increased over time (years): deciduous shrubs, from $11.5 \%$ to $26.1 \%$; evergreen shrubs, from $12.2 \%$ to $29.6 \%$; forbs, from $3.2 \%$ to $6.4 \%$; and graminoids, from $20.7 \%$ to $108.4 \%$. The cover of litter also increased, from $27.7 \%$ to $67.2 \%$ (Fig. 3; Supplementary data, File S1, Table S1 ${ }^{2}$ ). There was an increase in the cover of the following vascular plant species: Betula nana, Salix pulchra, Vaccinium vitis-idaea, Rubus chamaemorus, Carex aquatilis, Carex. bigelowii, Eriophorum angustifolium, Eriophorum russeolum, and Eriophorum vaginatum. There was a decrease in cover for only two species: Pedicularis lapponica and Luzula confusa. In Utqiagivik, graminoids increased in cover from $43.1 \%$ to $104.7 \%$ (Fig. 3; Supplementary data, File S1, Table $S 1^{2}$ ). The only vascular plant species to increase in cover were E. russeolum and E. triste, whereas the following species showed a decline in cover: Cerastium beeringianum, Stellaria humifusa, Alopecurus magellanicus, and Luzula arctica. Acrocarpous mosses have also declined in abundance in recent years. The goodness of fit between the cover of associated functional groups is provided for each location in the Supplementary data (File S1, Table $S 3^{2}$ ). The data used may be also be found in the Supplementary data (File $\mathrm{S3}^{2}$ ).

\section{Vascular plant diversity}

At both Atqasuk and Utqiagvik, the values for alpha, beta, and gamma diversity did not vary significantly between years (Table 1). However, the values for Shannon's index at Utqiagvik (1.4 to $\left.1.3, r^{2}=0.02\right)$ and Pielou's evenness $\left(0.8\right.$ to $\left.0.7, r^{2}=0.04\right)$ at Atqasuk varied significantly by year and declined over time. In Atqasuk, the values for gamma diversity were 26 in 2010 and 22 in 2019 (Supplementary data, File S1, Table S4 ${ }^{2}$ ). The notable changes in species presence were as follows: H. alpina was consistently present starting in 2016; 
Fig. 2. Abiotic variable change over years at both Atqasuk (red line) and Utqiagvik (blue line) for average air temperature $\left({ }^{\circ} \mathrm{C}\right)$, average thaw depth $(\mathrm{cm})$, average volumetric water content, thawing degree day sums, average soil temperature $\left({ }^{\circ} \mathrm{C}\right)$, and sum of precipitation $(\mathrm{cm})$.
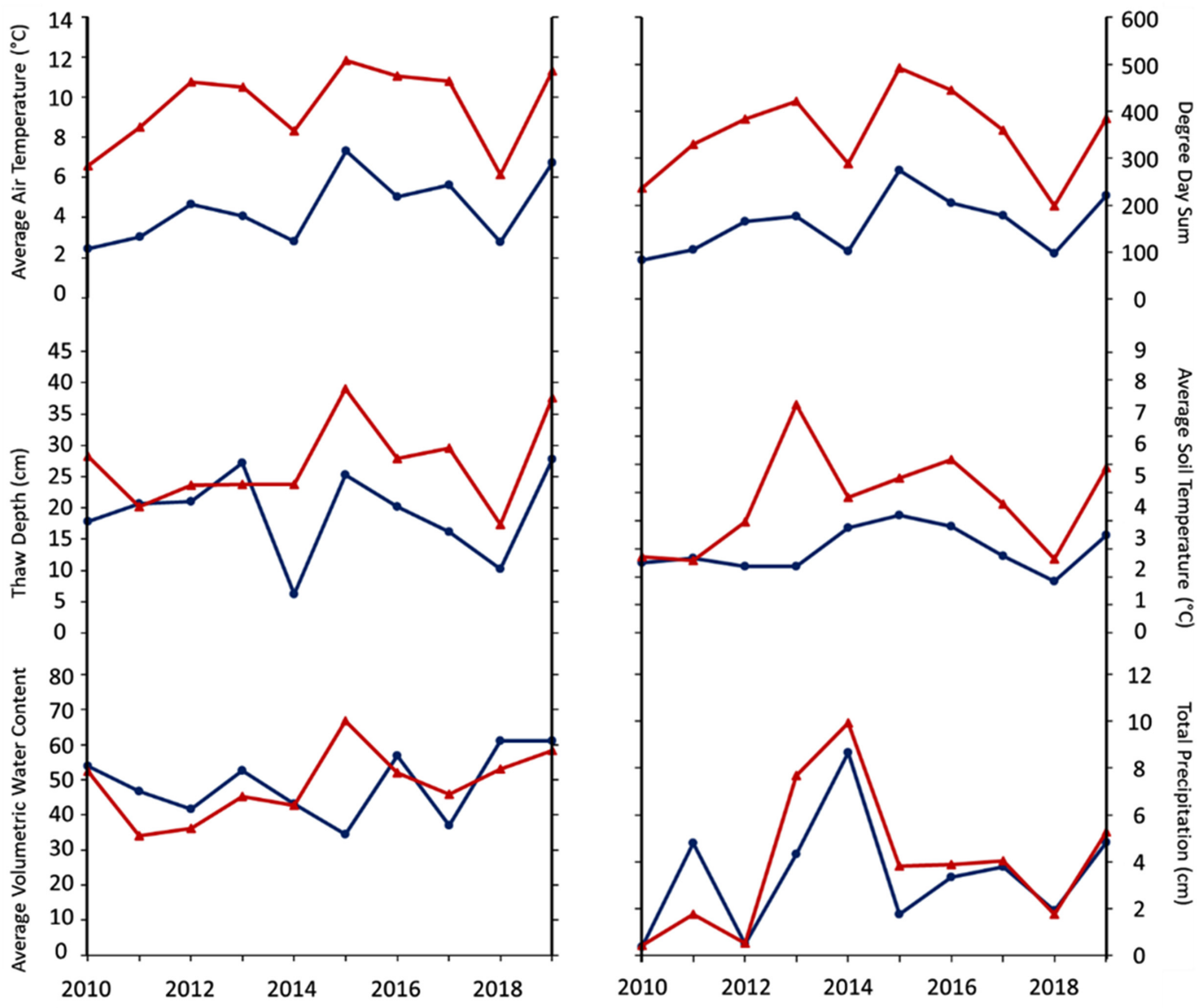

Fig. 3. Cover change over years at both Atqasuk and Utqiagivik.

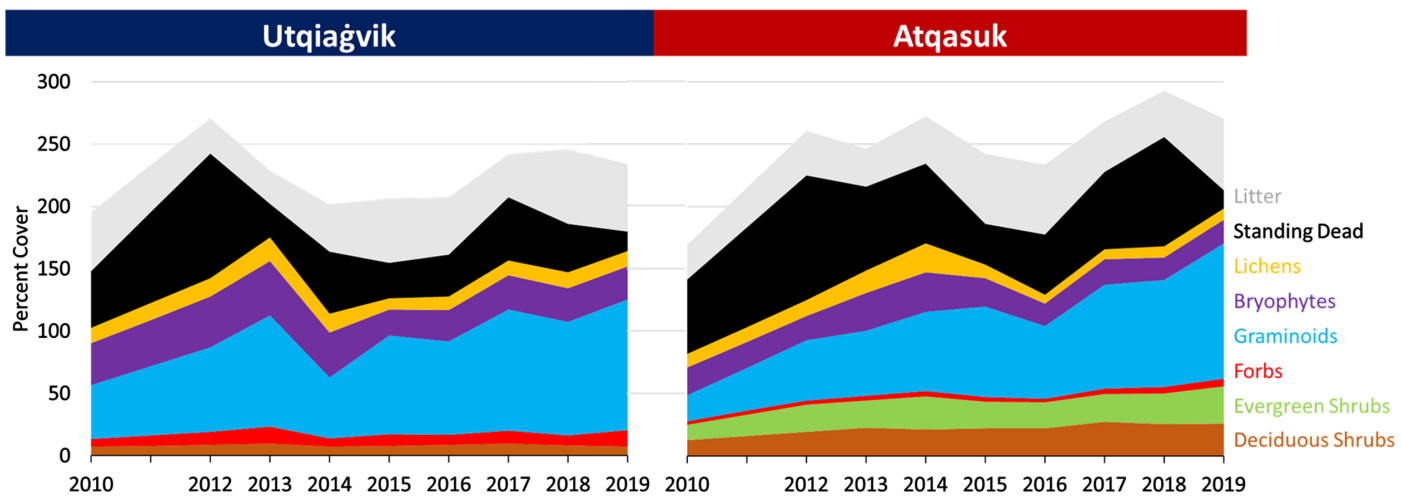

- Published by Canadian Science Publishing 
Table 1. Change in vascular plant diversity at Atqasuk and Utqiagivik between 2010 and 2019. Alpha, beta, Shannon and Evenness diversity indices were calculated for each plot $(n=30)$; the average index value and the standard deviation (in parentheses) are presented.

\begin{tabular}{|c|c|c|c|c|c|c|c|c|c|c|}
\hline & 2010 & 2012 & 2013 & 2014 & 2015 & 2016 & 2017 & 2018 & 2019 & $r^{2}$ \\
\hline \multicolumn{11}{|c|}{ Atqasuk grid } \\
\hline Alpha & $5.77(2.14)$ & $5.53(2.08)$ & $5.63(2.03)$ & $5.83(2.02)$ & $6.30(1.84)$ & $5.13(1.74)$ & $6.00(2.20)$ & $6.07(2.30)$ & $5.70(1.84)$ & 0 \\
\hline Beta & $0.22(0.08)$ & $0.22(0.08)$ & $0.23(0.08)$ & $0.23(0.08)$ & $0.25(0.07)$ & $0.21(0.07)$ & $0.23(0.08)$ & $0.23(0.09)$ & $0.26(0.08)$ & 0.01 \\
\hline Shannon & $1.34(0.45)$ & $1.27(0.41)$ & $1.27(0.41)$ & $1.29(0.44)$ & $1.29(0.38)$ & $1.20(0.41)$ & $1.27(0.39)$ & $1.21(0.44)$ & $1.23(0.39)$ & 0.01 \\
\hline Evenness & $0.81(0.12)$ & $0.79(0.11)$ & $0.79(0.12)$ & $0.76(0.17)$ & $0.72(0.15)$ & $0.77(0.12)$ & $0.75(0.13)$ & $0.70(0.19)$ & $0.72(0.13)$ & 0.04 \\
\hline \multicolumn{11}{|c|}{ Utqiaġvik grid } \\
\hline Gamma & 29 & 25 & 30 & 27 & 32 & 28 & 30 & 26 & 29 & 0.32 \\
\hline Shannon & $1.42(0.45)$ & $1.30(0.37)$ & $1.41(0.39)$ & $1.36(0.39)$ & $1.30(0.35)$ & $1.24(0.36)$ & $1.30(0.33)$ & $1.23(0.34)$ & $1.28(0.32)$ & 0.02 \\
\hline Evenness & $0.72(0.15)$ & $0.70(0.13)$ & $0.68(0.11)$ & $0.71(0.11)$ & $0.66(0.14)$ & $0.68(0.13)$ & $0.65(0.10)$ & $0.68(0.12)$ & $0.67(0.12)$ & 0.01 \\
\hline
\end{tabular}

Note: Gamma diversity represents the species richness for the site and is therefore a single value for each year. Linear mixed models were used to generate $r^{2}$ values for the relationship between diversity metrics and years; significant relationships are indicated in bold font. A listing of each species sampled each year is available in the Supplementary data (File S1, Table S2 ${ }^{2}$ ). 
Fig. 4. Height change of functional groups over years in Atqasuk and Utqiagivik.

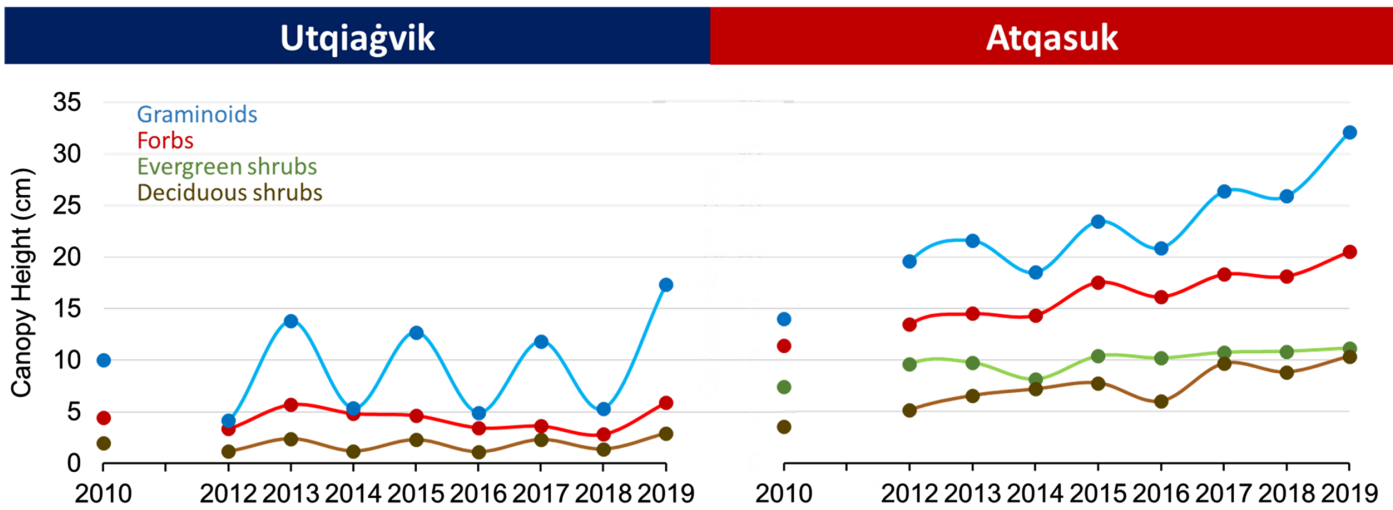

Luzula wahlenbergii disappeared from plots starting in 2016; Carex rariflora, Diapensia lapponica, Juncus bighumis, Lloydia serotina, Oxyria digyna, Poa arctica, Poa viviparum, and Potentilla hyparctica were intermittently present depending on the year. In Utqiagvik, the values for gamma diversity were 29 in 2010 and in 2019 (Supplementary data, File S1, Table S4 ${ }^{2}$ ). The notable changes in species presence were as follows: Festuca brachyphylla and Stellaria humifusa appeared less frequently in later years; Pedicularis lanata, P. sudetica, P. hyparctica, Ranunculus nivalis, and Ranunculus pallasii appeared more frequently in later years; Calamagrostis holmii, Draba lactea, and Ranunculus pygmaeus were intermittently observed depending on the year. The data used may be found in the Supplementary data, Files S4 and $\mathrm{S5}^{2}$.

\section{Vegetation height}

At Atqasuk, the heights of all functional groups increased over years: deciduous shrubs, from 11.5 to $20.5 \mathrm{~cm}, r^{2}=0.11$; evergreen shrubs from 7.4 to $11.2 \mathrm{~cm}, r^{2}=0.04$; forbs from 3.6 to $10.4 \mathrm{~cm}, r^{2}=0.19$; and graminoids from 14.0 to $32.1 \mathrm{~cm}, r^{2}=0.21$ (Fig. 4; Supplementary data, File S1, Table $S 5^{2}$ ). The growth height of the following species also increased with time (years): B. nana, S. pulchra, Cassiope tetragona, Ledum palustre, V. vitis-idaea, R. chamaemorus, C. aquatilus, C. bigelowii, E. russeolum, E. vaginatum, and Trisetum spicatum. At Utqiagivik, graminoids were the only functional group that increased in growth height over time (from 10.00 to $23.10 \mathrm{~cm}, r^{2}=0.21$ ) (Fig. 4; Supplementary data, File S1, Table S5 ${ }^{2}$ ). The growth height of the following species also increased with time (years): Salix rotundifolia, Petasites frigidus, Saxifraga cernua, Arctagrostis latifolia, Carex stans, Dupontia fisheri, E. russeolum, E. triste, L. confusa, and P. arctica. The data used may be found in the Supplementary data, Files $\mathrm{S} 6$ and $\mathrm{S7}^{2}$.

\section{Drivers of change}

At Atqasuk and Utqiagvik, plant cover was most closely associated with year, soil temperature, and soil moisture (Table 2). At Atqasuk, all taxa of vascular plants, except Cassiope tetragona and Ledum palustre, showed a relationship with year, whereas bryophytes and lichens did not, and were instead more likely to show a relationship with soil moisture. At Atqasuk, cover for many vascular taxa and pleurocarpous mosses was associated with soil temperature. Especially noticeable was a 5-fold increase in graminoid cover at Atqasuk over the 10 years studied. At Utqiagivik, there were fewer relationships; the only generalization to be made was that graminoids generally showed a relationship with year. 
Table 2. The relationship between vegetation cover and abiotic factors at Atqasuk and Utqiagvik.

\begin{tabular}{|c|c|c|c|c|c|c|c|c|c|}
\hline & Year & $\begin{array}{l}\text { Air temp. } \\
\text { (avg.) }\end{array}$ & $\begin{array}{l}\text { Air temp. } \\
\text { (max.) }\end{array}$ & $\begin{array}{l}\text { Degree } \\
\text { day (sum) }\end{array}$ & $\begin{array}{l}\text { Soil temp. } \\
\text { (avg.) }\end{array}$ & $\begin{array}{l}\text { Soil temp. } \\
\text { (max.) }\end{array}$ & $\begin{array}{l}\text { Thaw depth } \\
\text { (avg.) }\end{array}$ & $\begin{array}{l}\text { Precip. } \\
\text { (sum) }\end{array}$ & $\begin{array}{l}\text { Soil moist. } \\
\text { (avg.) }\end{array}$ \\
\hline \multicolumn{10}{|l|}{ Atqasuk grid } \\
\hline Deciduous shrub & 1289 & 1291 & 1185 & 1290 & 1185 & 1290 & 1153 & 1290 & 1288 \\
\hline Betula nana & 846 & 847 & 772 & 846 & 771 & 847 & 749 & 847 & 848 \\
\hline Salix pulchra & 582 & 585 & 536 & 584 & 537 & 584 & 542 & 585 & 586 \\
\hline Evergreen shrub & 1428 & 1427 & 1258 & 1427 & 1255 & 1427 & 1287 & 1428 & 1410 \\
\hline Cassiope tetragona & 618 & 619 & 562 & 619 & 562 & 615 & 559 & 618 & 620 \\
\hline Ledum palustre & 1055 & 1055 & 926 & 1055 & 926 & 1054 & 945 & 1054 & 1040 \\
\hline Vaccinium vitis-idaea & 1047 & 1047 & 944 & 8575 & 944 & 1046 & 930 & 1047 & 1043 \\
\hline Forb & 813 & 815 & 733 & 815 & 729 & 813 & 733 & 814 & 816 \\
\hline Rubus chamaemorus & 518 & 522 & 471 & 522 & 466 & 522 & 477 & 522 & 521 \\
\hline Graminoid & 2781 & 2779 & 2477 & 2782 & 2461 & 2782 & 2457 & 2781 & 2781 \\
\hline Carex aquatilis & 1446 & 1447 & 1251 & 1449 & 1247 & 1448 & 1238 & 1448 & 1445 \\
\hline Carex bigelowii & 277 & 597 & 543 & 792 & 543 & 596 & 540 & 596 & 592 \\
\hline Eriophorum angustifolium & 478 & 480 & 438 & 480 & 440 & 480 & 439 & 480 & 484 \\
\hline Eriophorum russeolum & 636 & 636 & 585 & 636 & 585 & 635 & 567 & 635 & 637 \\
\hline Eriophorum vaginatum & 1177 & 1176 & 1059 & 1177 & 1059 & 1175 & 1078 & 1175 & 1169 \\
\hline Trisetum spicatum & 577 & 578 & 465 & 578 & 471 & 578 & 541 & 577 & 579 \\
\hline Bryophyte & 2336 & 2334 & 2127 & 2339 & 2123 & 2337 & 2092 & 2336 & 2337 \\
\hline Acrocarpous moss & 1553 & 1551 & 1358 & 1551 & 1358 & 1550 & 1369 & 1550 & 1554 \\
\hline Pleurocarpous moss & 983 & 985 & 834 & 984 & 817 & 985 & 894 & 983 & 974 \\
\hline Lichen & 1254 & 1255 & 1092 & 1254 & 1093 & 1254 & 1133 & 1254 & 1241 \\
\hline Crustose & 327 & 327 & 287 & 327 & 289 & 327 & 235 & 327 & 329 \\
\hline Foliose & 839 & 839 & 745 & 840 & 747 & 839 & 731 & 839 & 837 \\
\hline Fruticose & 1081 & 1081 & 959 & 1187 & 959 & 1081 & 965 & 1080 & 1069 \\
\hline Standing dead & 3646 & 3649 & 3249 & 3761 & 3248 & 3647 & 3217 & 3647 & 3654 \\
\hline Leaf litter & 2942 & 2944 & 2697 & 2940 & 2695 & 2940 & 2552 & 2942 & 2911 \\
\hline
\end{tabular}


Table 2. (concluded).

\begin{tabular}{|c|c|c|c|c|c|c|c|c|c|}
\hline & Year & $\begin{array}{l}\text { Air temp. } \\
\text { (avg.) }\end{array}$ & $\begin{array}{l}\text { Air temp. } \\
\text { (max.) }\end{array}$ & $\begin{array}{l}\text { Degree } \\
\text { day (sum) }\end{array}$ & $\begin{array}{l}\text { Soil temp. } \\
\text { (avg.) }\end{array}$ & $\begin{array}{l}\text { Soil temp. } \\
\text { (max.) }\end{array}$ & $\begin{array}{l}\text { Thaw depth } \\
\text { (avg.) }\end{array}$ & $\begin{array}{l}\text { Precip. } \\
\text { (sum) }\end{array}$ & $\begin{array}{l}\text { Soil moist. } \\
\text { (avg.) }\end{array}$ \\
\hline \multicolumn{10}{|l|}{ Utqiaġvik grid } \\
\hline Deciduous shrub & 713 & 713 & 713 & 713 & 633 & 635 & 711 & 713 & 712 \\
\hline Salix rotundifolia & 689 & 689 & 688 & 689 & 614 & 614 & 689 & 689 & 690 \\
\hline Forb & 1562 & 1563 & 1561 & 1560 & 1339 & 1328 & 1535 & 1562 & 1566 \\
\hline Petasites frigidus & 623 & 622 & 623 & 622 & 551 & 550 & 625 & 622 & 622 \\
\hline Stellaria laeta & 562 & 562 & 563 & 563 & 498 & 497 & 557 & 562 & 561 \\
\hline Carex stans & 1820 & 1820 & 1818 & 1819 & 1656 & 1653 & 1825 & 1819 & 1822 \\
\hline Dupontia fisheri & 1516 & 1514 & 1514 & 1513 & 1341 & 1341 & 1520 & 1515 & 1515 \\
\hline Eriophorum russeolum & 1561 & 1560 & 1558 & 1560 & 1356 & 1355 & 1565 & 1561 & 1566 \\
\hline Eriophorum triste & 1408 & 1406 & 1409 & 1408 & 1259 & 1256 & 1421 & 1411 & 1414 \\
\hline Luzula arctica & 480 & 481 & 481 & 481 & 428 & 431 & 480 & 481 & 476 \\
\hline Luzula confusa & 703 & 703 & 702 & 702 & 640 & 634 & 706 & 702 & 706 \\
\hline Poa arctica & 1191 & 1188 & 1189 & 1189 & 1044 & 1046 & 1183 & 1189 & 1186 \\
\hline Fruticose & 949 & 948 & 949 & 949 & 860 & 860 & 948 & 950 & 950 \\
\hline Standing dead & 3788 & 3792 & 3791 & 3790 & 3358 & 3358 & 3801 & 3789 & 3794 \\
\hline Leaf litter & 3047 & 3047 & 3049 & 3047 & 2778 & 2771 & 3031 & 3049 & 3048 \\
\hline
\end{tabular}

Note: Values represent the widely applicable information criterion (WAIC) from Bayesian regression models between cover groups. WAIC values were determined after regressing a single log linked cover group variable to every other functional group sequentially. Values can be compared horizontally with lower numbers indicating a

better fit. A Poisson distribution was assumed. Plot location $(n=30)$ was considered a source of random error. Column and row headers indicate abiotic factors and

functional group respectively. WAIC values from significant models are indicated in bold font. 
At Atqasuk and Utqiagvik, the growth height of vascular plants was associated with year (Table 3). At Utqiagvik, there were also a number of relationships with air temperature.

\section{Discussion}

The vegetation of the Arctic is changing (Frost et al. 2020). Graminoid cover increased 5 -fold at Atqasuk over 10 years; graminoid cover also increased at Utqiagivik. Changes in vegetation cover over time in Arctic communities are important to document because plant community composition can greatly influence the overall energy balance of tundra ecosystems. The energy balance of tundra ecosystems is crucial for ecosystem processes, such as carbon and nutrient cycling, plant growth and productivity, and microbial activity (Lund et al. 2014). Woody species (i.e., deciduous and evergreen shrubs) have been shown to greatly alter belowground carbon exchange rates (Parker et al. 2020); thus, dramatic increases in the cover of woody species have the potential to greatly alter ecosystem structure and function. Additionally, encroachment of tall-statured shrubs shades neighboring plants, which has been shown to restrict plant growth (Graglia et al. 1997).

Increases in shrub and graminoid cover affect more than plant-plant interactions. Shading imposed from neighboring shrubs has been shown to delay flowering, which could reduce (or eliminate) pollinator visitation and (or) berry production (Hoye et al. 2013). Changes in berry production could affect the populations of mammalian and avian species that rely on berries as a food source. Graminoids and deciduous shrubs are the primary food sources for most Arctic herbivores. Long-term herbivore exclusion experiments have shown that the absence of herbivory (i.e., lemmings, caribou) greatly alters several ecosystem properties, including labile soil nitrogen, thaw depth, water table, and $\mathrm{CH}_{4}$ exchange (Lara et al. 2017; Sundqvist et al. 2019). The presence of herbivores has also caused a shift in community composition in wet meadow communities, from predominately graminoids to mosses (Lara et al. 2017). In a short-term Tibetan alpine meadow, Liu et al. (2017) demonstrated that the phenology of common forbs was sensitive to both mowing and nitrogen addition. Enhanced nitrogen levels in soils delayed flowering events by approximately a week and half, while mowing and nitrogen additions hastened the first and last flowering times by as much as a week. Herbivory in increasingly nutrient rich tundra facilitated by increasing thaw depths may cause plant phenology to accelerate for tundra species. More research is needed to understand the various trophic cascades associated with shifts in vegetation community composition, but documenting vegetation change over time and in response to warming is the first step to understanding how the Arctic is responding to a warming climate (Post and Forchhammer 2008).

Species diversity (both Shannon's index and Pielou's evenness) declined at both sites over time, owing to a disproportionate increase in the abundance of species. Measures of species richness (alpha, beta, and gamma diversity) did not change. Declines in species diversity contradict previous studies showing increased species diversity over time (Villarreal et al. 2012; Lokken et al. 2020) and the general pattern of increased diversity at warmer locations (Walker 1995). Because species diversity is a function of species evenness, increases in cover for the dominant species without the addition of newly introduced species would cause an overall decrease in diversity. Because the study sites span a wide range of community types, it is unlikely that a 30-plot sample is sufficient to capture all species present in the surrounding area. Previous studies, which focused on one or two community types, showed increased species richness (gamma diversity) over time as the abiotic conditions (e.g., soil moisture, soil temperature, etc.) changed, and new species, including nearby species that were simply absent from plots, migrated into the plots. Another consideration when determining trends in species diversity is whether the species in question were either uncommon or rare at the beginning of the study. For instance, while P. arctica was 
Table 3. The relationship between plant height (by growth form and species) and abiotic factors at Utqiagvik and Atqasuk.

\begin{tabular}{|c|c|c|c|c|c|c|c|c|c|}
\hline & Year & $\begin{array}{l}\text { Air temp. } \\
\text { (mean) }\end{array}$ & $\begin{array}{l}\text { Air temp. } \\
\text { (max.) }\end{array}$ & $\begin{array}{l}\text { Degree } \\
\text { day (sum) }\end{array}$ & $\begin{array}{l}\text { Soil temp. } \\
\text { (mean) }\end{array}$ & $\begin{array}{l}\text { Soil temp. } \\
\text { (max.) }\end{array}$ & $\begin{array}{l}\text { Thaw depth } \\
\text { (mean) }\end{array}$ & $\begin{array}{l}\text { Precip. } \\
\text { (sum) }\end{array}$ & $\begin{array}{l}\text { Soil moist. } \\
\text { (mean) }\end{array}$ \\
\hline \multicolumn{10}{|l|}{ Atqasuk grid } \\
\hline Deciduous shrub & 0.11 & 0.02 & 0.03 & 0.01 & 0.00 & 0.00 & 0.02 & 0.00 & 0.00 \\
\hline Betula nana & 0.07 & 0.01 & 0.02 & 0.01 & 0.00 & 0.00 & 0.00 & 0.00 & 0.00 \\
\hline Salix pulchra & 0.31 & 0.03 & 0.08 & 0.01 & 0.02 & 0.01 & 0.10 & 0.00 & 0.00 \\
\hline Evergreen shrub & 0.04 & 0.01 & 0.02 & 0.01 & 0.04 & 0.03 & 0.00 & 0.00 & 0.00 \\
\hline Cassiope tetragona & 0.03 & 0.00 & 0.01 & 0.00 & 0.00 & 0.00 & 0.00 & 0.00 & 0.00 \\
\hline Ledum palustre & 0.05 & 0.00 & 0.02 & 0.00 & 0.04 & 0.02 & 0.00 & 0.00 & 0.00 \\
\hline Vaccinium vitis-idaea & 0.10 & 0.04 & 0.05 & 0.02 & 0.00 & 0.00 & 0.01 & 0.00 & 0.00 \\
\hline Forb & 0.19 & 0.02 & 0.03 & 0.00 & 0.02 & 0.01 & 0.02 & 0.02 & 0.00 \\
\hline Rubus chamaemorus & 0.30 & 0.03 & 0.06 & 0.00 & 0.02 & 0.02 & 0.08 & 0.00 & 0.00 \\
\hline Graminoid & 0.21 & 0.04 & 0.09 & 0.01 & 0.03 & 0.02 & 0.02 & 0.00 & 0.01 \\
\hline Carex aquatilus & 0.31 & 0.04 & 0.09 & 0.01 & 0.04 & 0.03 & 0.04 & 0.00 & 0.03 \\
\hline Carex bigelowii & 0.15 & 0.02 & 0.06 & 0.00 & 0.00 & 0.00 & 0.00 & 0.00 & 0.00 \\
\hline Eriophorum russeolum & 0.44 & 0.05 & 0.11 & 0.02 & 0.10 & 0.12 & 0.04 & 0.06 & 0.00 \\
\hline Eriophorum vaginatum & 0.18 & 0.05 & 0.13 & 0.02 & 0.00 & 0.00 & 0.01 & 0.01 & 0.00 \\
\hline Trisetum spicatum & 0.30 & 0.03 & 0.08 & 0.00 & 0.02 & 0.00 & 0.17 & 0.01 & 0.00 \\
\hline \multicolumn{10}{|l|}{ Utqiagivik grid } \\
\hline Deciduous shrub & 0.06 & 0.04 & 0.03 & 0.02 & 0.01 & 0.01 & 0.00 & 0.00 & 0.00 \\
\hline Salix pulchra & 0.02 & 0.06 & 0.10 & 0.07 & 0.02 & 0.01 & 0.00 & 0.05 & 0.00 \\
\hline Salix rotundifolia & 0.08 & 0.02 & 0.01 & 0.01 & 0.01 & 0.01 & 0.01 & 0.01 & 0.00 \\
\hline Evergreen shrub & - & - & - & - & - & - & - & - & - \\
\hline Forb & 0.04 & 0.05 & 0.05 & 0.03 & 0.00 & 0.00 & 0.02 & 0.00 & 0.01 \\
\hline Petasites frigidus & 0.05 & 0.04 & 0.04 & 0.02 & 0.00 & 0.00 & 0.02 & 0.00 & 0.05 \\
\hline Saxifraga cernua & 0.16 & 0.09 & 0.18 & 0.07 & 0.08 & 0.06 & 0.00 & 0.04 & 0.00 \\
\hline Stellaria laeta & 0.05 & 0.15 & 0.12 & 0.10 & 0.00 & 0.00 & 0.05 & 0.00 & 0.03 \\
\hline Graminoid & 0.21 & 0.14 & 0.14 & 0.09 & 0.00 & 0.00 & 0.00 & 0.00 & 0.01 \\
\hline Arctagrostis latifolia & 0.20 & 0.05 & 0.05 & 0.02 & 0.00 & 0.02 & 0.08 & 0.00 & 0.01 \\
\hline Carex stans & 0.20 & 0.11 & 0.11 & 0.06 & 0.00 & 0.00 & 0.00 & 0.00 & 0.01 \\
\hline Dupontia fisheri & 0.26 & 0.24 & 0.24 & 0.17 & 0.00 & 0.00 & 0.00 & 0.00 & 0.00 \\
\hline Eriophorum russeolum & 0.39 & 0.18 & 0.22 & 0.12 & 0.01 & 0.01 & 0.01 & 0.00 & 0.00 \\
\hline Eriophorum triste & 0.34 & 0.21 & 0.22 & 0.13 & 0.00 & 0.00 & 0.01 & 0.01 & 0.00 \\
\hline Luzula arctica & 0.00 & 0.07 & 0.06 & 0.06 & 0.03 & 0.09 & 0.12 & 0.01 & 0.19 \\
\hline Luzula confusa & 0.11 & 0.10 & 0.13 & 0.10 & 0.11 & 0.14 & 0.17 & 0.00 & 0.00 \\
\hline Poa arctica & 0.12 & 0.14 & 0.12 & 0.10 & 0.01 & 0.03 & 0.00 & 0.00 & 0.00 \\
\hline
\end{tabular}

Note: Values represent marginal $r^{2}$ values from general linear mixed models regressing functional group average max height with abiotic factors including time. Plot location and year were considered sources of random error ( $n$ varies by functional group and site, see the Supplementary data, File $S 1$, Table $S 5^{2}$ ). Column headers indicate abiotic variables and row headers indicate broad functional groups. Values in bold font represent significant effects. 
widespread over the Utqiagivik ARCSS grid, its distribution over the Atqasuk ARCSS grid was quite low, even at the beginning of the observation period, appearing only in 2015 in Atqasuk (Supplementary data, File S1, Table S4 ${ }^{2}$ ). Over longer observation periods, it is likely that new species will invade both regions and reverse the observed trend of the decline in species diversity at the sites. Additionally, more intense herbivory could influence this trend: caribou can cause declines in lichen populations (Bernes et al. 2015; Sundqvist et al. 2019); reindeer exclusion experiments have shown that plants with low stature and low leaf area experience declines in the absence of grazing (Kaarlejarvi et al. 2017). While grazing tends to increase species diversity, it could be offset by soil nutrient inputs, such as nitrogen, which may increase as a result of herbivory (Borer et al. 2014; Kaarlejarvi et al. 2017). Signs of intense grazing are neither obvious nor well quantified at the plot level, and are a focus of future investigation.

The increase in plant cover observed in this study, particularly at Atqasuk, is consistent with the recent greening of the North Slope of Alaska, which has been detected by satellite observations (Frost et al. 2020). Other studies have attributed green trends with changes in photosynthetic biomass, green leaf area index (LAI), plant cover, and vegetation productivity (Jia et al. 2009; Forbes et al. 2010; Beck and Goetz 2011; Epstein et al. 2012; Bhatt et al. 2013; Pattison et al. 2015; Ju and Masek 2016; Kobayashi et al. 2018; Walther et al. 2018). Greening trends across the Arctic are complex, and not all studies come to the same conclusions (Beamish et al. 2020; Myers-Smith et al. 2020), and a disagreement between sensing platforms and approaches has been observed (Guay et al. 2014). Common spectral indices used to detect vegetation, such as the normalized difference vegetation index (NDVI), have been shown to be sensitive to nonvegetation landscape features such as water in saturated tundra, snow cover, and even shadow (Gamon et al. 2013; Raynolds et al. 2013; Pattison et al. 2015). Additionally, plant moisture content, such as the moisture in sphagnum moss mounds, can drastically alter NDVI by as much as $80 \%$, depending on moisture levels (May et al. 2018). Therefore, it is essential that vegetation monitoring be coupled with remote sensing to understand the drivers of change.

\section{Drivers of vegetation change}

Overall, the best predictors for change in either cover or growth height were year, soil temperature, soil moisture, or air temperature. The strong relationship between plant cover and plant growth height with year implies a cumulative response to regional climate warming. The correspondences between vegetation cover, soil moisture, and temperature of the current year's growing season suggests considerable plasticity in overall tundra vegetation growth between years (Walker et al. 1994; van der Wal and Stien 2014). Biomass in tundra regions has been linked to soil temperature (Hill and Henry 2011; Natali et al. 2012). Soil moisture and precipitation are known constraints on the growth of Arctic vegetation (Chapin et al. 1996; Blok et al. 2011). In our study, precipitation was a modest predictor of cover change, but did not successfully predict changes in growth height. Soil moisture was an important predictor in Atqasuk, and a modest predictor of cover change in Utqiagvik, as well as a modest predictor of height change at either site. This is reasonable, given that past work has indicated that soil moisture is a limiting factor for vegetation growth (Chapin et al. 1995; Gamon et al. 2013; Botting 2015). Thaw depth was a modest predictor of cover change at either research site and was not as well-represented as soil temperature for predicting plant height change at either site, although thaw depth was associated with community composition and growth (Schuur et al. 2007; Lantz et al. 2009). It would be beneficial for future studies to discern the best groups of predictors for broad functional groups and the most common taxa, via multivariate modeling on this dataset. 


\section{Comparison between regions}

The larger documented change at the lower Arctic site, Atqasuk, relative to the higher Arctic site, Utqiagvik, is consistent with previous studies that found greater changes in the cover of shrubs at warmer locations (Walker et al. 2006; Elmendorf et al. 2012). While Utqiagivik is considered a coastal low Arctic subzone $C$ site, it may slowly transition to more resemble low arctic subzone $\mathrm{D}$ communities if erect shrubs become more dominant, and an influx of southern species that are better adapted to warm weather move in; anecdotal evidence indicates the presence of several Salix species present in the region, which were not sampled during the 1980s (Murray and Murray 1978). Global monitoring networks across the tundra biome have shown a general increase in the stature of most tundra plants and consistent increases in cover over time (particularly for shrubs), which is consistent with our own findings (Elmendorf et al. 2012; Bjorkman et al. 2018; Myers-Smith et al. 2019; Bjorkman et al. 2020).

Our results are consistent with experimental warming studies that have shown an increase in shrub and graminoid cover with temperature at other tundra locations (Callaghan et al. 2011; Elmendorf et al. 2012; Bjorkman et al. 2020) and at adjacent sites at Atqasuk and Utqiagvik, which also included an increase in canopy height (Hollister et al. 2015). Increases in the heights of graminoids in Utqiagvik and of graminoids and shrubs in Atqasuk are consistent with findings from other research that showed with warming and time, graminoids increase in height in cooler regions and deciduous shrubs increase in height in warmer regions (Elmendorf et al. 2012; Jorgenson et al. 2015). A similar longterm monitoring study on Qikiqtaruk-Herschel Island in Canada found that average canopy height doubled from 1999 to 2017, and that tundra shrub height increased and was driven by sensitivity to summer growing temperatures (Myers-Smith et al. 2019). The one notable exception is warming experiments often show a decline in bryophytes and lichens as vascular plants increase; here, we show considerable variability in the cover of these taxa, with the only significant change being a decline in acrocarpous mosses at Utqiagvik. Jorgenson et al. (2015) noted decreases in the cover of acrocarpous mosses in a low Arctic study in the Arctic National Wildlife Refuge, while the cover of other bryophytes remained unchanged, suggesting that a decline in acrocarpous mosses may be common in more than one coastal Arctic ecosystem. Findings from warming experiments in plots adjacent to this study in Utqiagvik and Atqasuk also suggest that the lack of a consistent decrease in bryophyte and lichen cover is likely due to considerable variability in cover between years (Hollister et al. 2015). Given that the average cover of vascular plants has only approached full cover $(100 \%)$ in the past few years, and there is a considerable amount of open ground, it is therefore possible that vascular plants have not yet imposed considerable shading or considerable levels of other adverse effects, such as decreasing nutrient availability, on nonvascular plants. Inconsistent trends in bryophyte cover could also be attributed to fluctuations in lemming populations, particularly at Utqiagvik, which have been shown to drastically reduce graminoid cover and promote bryophyte cover (Lara et al. 2017). Herbivory coupled with sensitivity to even small fluctuations in temperature (Hollister et al. 2015) may explain much of the interannual variability in tundra vegetation cover (Johnson et al. 2011). Additionally, although not a focus of this study, there has been noticeable ice-wedge degradation around a few plots, which may have contributed to changes in plant cover or growth height.

The cover of standing dead plants and leaf litter were somewhat inverse to each other at both sites (Supplementary data, File S1, Table S1 ${ }^{2}$ ). Other studies have indicated that standing dead cover fluctuates between years as a function of leaf retention time (Knapp and Seastedt 1986) and herbivory, especially during years with large populations of lemmings (Villarreal et al. 2012). Both processes may account for the increase in leaf litter. 
It is probable that, at least for our study site (Atqasuk), much of the increase in leaf litter could be attributed to the large increase in graminoid cover. Standing dead and leaf litter cover are important to include in vegetation cover change studies because they influence the composition of the surrounding plant community and the overall productivity of the ecosystem (Knapp and Seastedt 1986). Leaf litter accumulation coupled with increased temperatures over time also influences decomposition rates, which has the potential to alter the rate of carbon exchange, and therefore the overall carbon budget, in the tundra (McLaren et al. 2017; Parker et al. 2018).

There are several sources of uncertainty that have not already been noted in this study. Despite sampling each plot within the same 14 day-of-the-year range across years, vegetation measurements were spread across the season and the frequency of abiotic measurements was up to a 2-week interval. The asynchrony between measurements can mask the associations. For example, within-season variability in moisture levels, especially for mosses, can influence cover estimates, and early sampling during a cold summer or later sampling during a warm dry year could contribute to annual differences. Lastly, there is evidence that the nongrowing season temperature may be an important determinant of plant productivity (Miao et al. 2020), which was not addressed in this study, and we did not account for the cumulative effects of previous years on each year (van der Wal and Stien 2014).

\section{Conclusions}

Our results show that the plant cover and plant height increased from 2010 to 2019 at our two research sites, which were distinguished by climatic factors and geographical distance. While plant cover and growth height were associated with many abiotic factors such as soil moisture and soil temperature, most of the changes in vegetation were best predicted by year. At both sites, significant cover change was driven by shifts in species within the genera Carex and Eriophorum. In Atqasuk, there was more cover change in shrubs than in Utqiagvik. Diversity indices at both sites indicated that species evenness decreased over the monitoring period. Given the similarity of these changes between sites and the consistency of findings with adjacent warming experiments (Hollister et al. 2015), it is likely that the increase in plant cover at both sites is the result of regional climate warming.

Documenting and understanding vegetative and environmental changes is important for many reasons. Successfully predicting changes as natural communities experience climate change will allow researchers and natural resource managers to better maintain ecosystem services and natural resources. To understand the bottom-up effects within ecosystems, it is necessary to understand the plant community. Plant community metrics, such as cover and height, are useful for understanding the influence of competition, albedo, and habitat suitability. An ever-evolving awareness of how environmental abiotic factors influence the characteristics of plant communities across the Arctic is necessary to develop more useful models for predicting changes. It would be useful to develop a multivariate set of models to predict changes that may integrate phenological and plant trait observations with vegetation cover. Additionally, investigating whether satellite or aerial imagery corroborates our findings at these sites would be helpful for better understanding the changes in and around the greater region.

\section{Acknowledgements}

The authors would like to thank all past and present members of the Arctic Ecology Program (AEP) at the Grand Valley State University for inspiration and assistance with the collection of vegetation cover measurements. We also thank the past and present members of the Systems Ecology Lab (SEL) at the University of Texas at El Paso for assistance with the 
abiotic measurement collections. Logistics was provided by UIC Science and we thank them and the communities of Atqasuk and Utqiagvik for their support. We also thank the anonymous reviewers whose criticism strengthened this manuscript. This study was made possible with funding from the National Science Foundation $(0856516,1432277,1504224$, 1836839). Data are available from the Arctic Data Centre.

\section{Author contributions}

J.H. wrote the manuscript, performed all statistical analyses, and collected vegetation cover measurements; R.H. helped to provide funding for the study, helped co-write the manuscript, and assisted with data analyses; T.B. helped to formulate the study design and collected the vegetation cover measurements; C.T. helped to provide funding for the study, contributed abiotic data, and revised the manuscript; K.B. helped to write the manuscript and collected vegetation cover measurements; J.M., R.B., and J.L. established the current vegetation plots, led early vegetation cover measurements, and revised the manuscript; H.C. collected vegetation cover measurements and revised the manuscript; S.V., M.O., and T.F. collected the abiotic measurements and revised the manuscript.

\section{References}

AMAP. 2019. AMAP Climate Change Update 2019: An Update to Key Findings of Snow, Water, Ice and Permafrost in the Arctic (SWIPA) 2017. Arctic Monitoring and Assessment Program (AMAP), Oslo, Norway, pp. 1-12.

Anisimov, O., and Reneva, S. 2006. Permafrost and changing climate: The Russian perspective. Ambio, 35(4): 169-175. doi: 10.1579/0044-7447(2006)35[169:PACCTR]2.0.CO;2. PMID: 16944641.

Arft, A.M., Walker, M.D., Gurevitch, J., Alatalo, J.M., Bret-Harte, M.S., Dale, M., et al. 1999. Responses of tundra plants to experimental warming: Meta-analysis of the international tundra experiment. Ecol. Monogr. 69(4): 491-511. doi: 10.1890/0012-9615(1999)069[0491:ROTPTE]2.0.CO;2.

Asmus, A.L., Chmura, H.E., Hoye, T.T., Krause, J.S., Sweet, S.K., Perez, J.H., et al. 2018. Shrub shading moderates the effects of weather on arthropod activity in arctic tundra. Ecol. Entomol. 43(5): 647-655. doi: 10.1111/een.12644.

Augustine, D.J., and McNaughton, S.J. 1998. Ungulate effects on the functional species composition of plant communities: Herbivore selectivity and plant tolerance. J. Wildl. Manage. 62(4): 1165-1183. doi: 10.2307/3801981.

Barton, K. 2019. MuMIn: Multi-Model Inference. R package version 1.43.15. Available from https://CRAN.Rproject.org/package=MuMIn.

Bates, D., Maechler, M., Bolker, B., and Walker, S. 2015. Fitting Linear Mixed-Effects Models Using lme4. J. Statist. Softw. 67(1): 1-48. doi: 10.18637/jss.v067.i01.

Beamish, A., Raynolds, M.K., Epstein, H., Frost, G.V., Macander, M.J., Bergstedt, H., et al. 2020. Recent trends and remaining challenges for optical remote sensing of Arctic tundra vegetation: A review and outlook. Remote Sens. Environ. 246: 111872. doi: 10.1016/j.rse.2020.111872.

Beck, P.S.A., and Goetz, S.J. 2011. Satellite observations of high northern latitude vegetation productivity changes between 1982 and 2008: ecological variability and regional differences. Environ. Res. Lett. 6(4): 045501. doi: $10.1088 / 1748-9326 / 6 / 4 / 045501$.

Bernes, C., Brathen, K.A., Forbes, B.C., Speed, J.D.M., and Moen, J. 2015. What are the impacts of reindeer/caribou (Rangifer tarandus L.) on arctic and alpine vegetation? A systematic review. Environ. Evidence 4(1): 4. doi: 10.1186/ s13750-014-0030-3.

Bhatt, U.S., Walker, D.A., Raynolds, M.K., Bieniek, P.A., Epstein, H.E., Comiso, J.C., et al. 2013. Recent declines in warming and vegetation greening trends over Pan-Arctic Tundra. Remote Sens. 5(9): 4229-4254. doi: 10.3390/ rs5094229.

Bjorkman, A.D., Garcia Criado, M., Myers-Smith, I.H., Ravolainen, V., Jonsdottir, I.S., Westergaard, K.B., et al. 2020. Status and trends in Arctic vegetation: Evidence from experimental warming and long-term monitoring. Ambio, 49(3): 678-692. doi: 10.1007/s13280-019-01161-6. PMID: 30929249.

Bjorkman, A.D., Myers-Smith, I.H., Elmendorf, S.C., Normand, S., Rueger, N., Beck, P.S.A., et al. 2018. Plant functional trait change across a warming tundra biome. Nature, 562(7725): 57. doi: 10.1111/nph.15592. PMID: 30258229.

Blok, D., Sass-Klaassen, U., Schaepman-Strub, G., Heijmans, M.M.P.D., Sauren, P., and Berendse, F. 2011. What are the main climate drivers for shrub growth in Northeastern Siberian tundra?. Biogeosciences, 8(5): 1169-1179. doi: 10.5194/bg-8-1169-2011.

Borer, E.T., Seabloom, E.W., Gruner, D.S., Harpole, W.S., Hillebrand, H., Lind, E.M., et al. 2014. Herbivores and nutrients control grassland plant diversity via light limitation. Nature, 508(7497): 517. doi: 10.1038/nature13144.

Botting, T.F. 2015. Documenting annual differences in vegetation cover, height and diversity near Barrow, Alaska. M.Sc. thesis, Grand Valley State University, Allendale.

Bürkner, P.C. 2018. Advanced Bayesian multilevel modeling with the R Package BRMS. R J. 10(1): 395-411. doi: 10.32614/RJ-2018-017. 
Callaghan, T.V., Tweedie, C.E., Akerman, J., Andrews, C., Bergstedt, J., Butler, M.G., et al. 2011. Multi-Decadal changes in tundra environments and ecosystems: Synthesis of the International Polar Year - Back to the Future Project (IPY-BTF). Ambio, 40(6): 705-716. doi: 10.1007/s13280-011-0179-8. PMID: 21954732.

CAVM Team. 2003. Circumpolar Arctic Vegetation Map. (1:7,500,000 scale). Conservation of Arctic Flora and Fauna (CAFF) Map No. 1. U.S. Fish and Wildlife Service, Anchorage, Alaska.

Chapin, F.S. 1983. Direct and indirect effects of temperature on Arctic plants. Polar Biol. 2(1): 47-52.

Chapin, F.S., BretHarte, M.S., Hobbie, S.E., and Zhong, H.L. 1996. Plant functional types as predictors of transient responses of arctic vegetation to global change. J. Veg. Sci. 7(3): 347-358. doi: 10.1007/BF00258285.

Chapin, F.S., McGuire, A.D., Randerson, J., Pielke, R., Baldocchi, D., Hobbie, S.E., et al. 2000. Arctic and boreal ecosystems of western North America as components of the climate system. Global Change Biol. 6: 211-223. doi: 10.1046/j.1365-2486.2000.06022.x.

Chapin, F.S., Shaver, G.R., Giblin, A.E., Nadelhoffer, K.J., and Laundre, J.A. 1995. Responses of Arctic tundra to experimental and observed changes in climate. Ecology, 76(3): 694-711. doi: 10.2307/1939337.

Davidson, E.A., and Janssens, I.A. 2006. Temperature sensitivity of soil carbon decomposition and feedbacks to climate change. Nature, 440(7081): 165-173. doi: 10.1088/1748-9326/aba470. PMID: 16525463.

Elmendorf, S.C., Henry, G.H.R., Hollister, R.D., Bjork, R.G., Bjorkman, A.D., Callaghan, T.V., et al. 2012. Global assessment of experimental climate warming on tundra vegetation: heterogeneity over space and time. Ecol. Lett. 15(2): 164-175. doi: 10.1111/j.1461-0248.2011.01716.x.

Epstein, H.E., Raynolds, M.K., Walker, D.A., Bhatt, U.S., Tucker, C.J., and Pinzon, J.E. 2012. Dynamics of aboveground phytomass of the circumpolar Arctic tundra during the past three decades. Environ. Res. Lett. 7(1): 015506. doi: 10.1088/1748-9326/7/1/015506.

Forbes, B.C., Macias Fauria, M., and Zetterberg, P. 2010. Russian Arctic warming and 'greening' are closely tracked by tundra shrub willows. Global Change Biol. 16(5): 1542-1554. doi: 10.1111/j.1365-2486.2009.02047.x.

Frost, G.V., Bhatt, U.S., Epstein, H.E., Myers-Smith, I., Phoenix, G.K., Berner, L.T., et al. 2020. Tundra Greenness. Arctic Report Card, 2020: 1-11.

Gamon, J.A., Huemmrich, K.F., Stone, R.S., and Tweedie, C.E. 2013. Spatial and temporal variation in primary productivity (NDVI) of coastal Alaskan tundra: Decreased vegetation growth following earlier snowmelt. Remote Sens. Environ. 129: 144-153. doi: 10.1016/j.rse.2012.10.030.

Gauthier, G., Bety, J., Cadieux, M.C., Legagneux, P., Doiron, M., Chevallier, C., et al. 2013. Long-term monitoring at multiple trophic levels suggests heterogeneity in responses to climate change in the Canadian Arctic tundra. Philos Trans. R Soc. Lond B. Biol. Sci. 368(20120482): 1-12. doi: 10.1098/rstb.2012.0482.

Gilg, O., Sittler, B., and Hanski, I. 2009. Climate change and cyclic predator-prey population dynamics in the High Arctic. Global Change Biol. 15: 2634-2652. doi: 10.1111/j.1365-2486.2009.01927.x.

Graglia, E., Jonasson, S., Michelsen, A., and Schmidt, I.K. 1997. Effects of shading, nutrient application and warming on leaf growth and shoot densities of dwarf shrubs in two arctic-alpine plant communities. Ecoscience, 4(2): 191-198. doi: 10.1080/11956860.1997.11682395.

Grigoriev, A.A., Shalaumova, Y.V., Erokhina, O.V., Sokovnina, S.Y., Vatolina, E.I., and Wilmking, M. 2020. Expansion of Juniperus sibirica Burgsd. as a response to climate change and associated effect on mountain tundra vegetation in the Northern Urals. J. Mountain Sci. 17(10): 2339-2353. doi: 10.1007/s11629-019-5925-6.

Guay, K.C., Beck, P.S.A., Berner, L.T., Goetz, S.J., Baccini, A., and Buermann, W. 2014. Vegetation productivity patterns at high northern latitudes: a multi-sensor satellite data assessment. Global Change Biol. 20(10): 3147-3158. doi: $10.1111 / g c b .12647$.

Hallinger, M., Manthey, M., and Wilmking, M. 2010. Establishing a missing link: warm summers and winter snow cover promote shrub expansion into alpine tundra in Scandinavia. New Phytol. 186(4): 890-899. doi: 10.1111/ j.1469-8137.2010.03223.x.

Harsch, M.A., Hulme, P.E., McGlone, M.S., and Duncan, R.P. 2009. Are treelines advancing? A global meta-analysis of treeline response to climate warming. Ecol. Lett. 12(10): 1040-1049. doi: 10.1111/j.1461-0248.2009.01355.x.

Hill, G.B., and Henry, G.H.R. 2011. Responses of High Arctic wet sedge tundra to climate warming since 1980. Global Change Biol. 17(1): 276-287.

Hinkel, K.M., and Nelson, F.E. 2003. Spatial and temporal patterns of active layer thickness at Circumpolar Active Layer Monitoring (CALM) sites in northern Alaska, 1995-2000. J. Geophys. Res. Atmos. 108(D2): 8168. doi: 10.1111/ j.1365-2486.2010.02244.x.

Hobbie, S.E. 1996. Temperature and plant species control over litter decomposition in Alaskan tundra. Ecol. Monogr. 66(4): 503-522. doi: 10.2307/2963492.

Hollister, R.D., and Flaherty, K.J. 2010. Above- and below-ground plant biomass response to experimental warming in northern Alaska. Appl. Veg. Sci. 13(3): 378-387. doi: 10.1111/j.1654-109X.2010.01079.x.

Hollister, R.D., Webber, P.J., Nelson, F.E., and Tweedie, C.E. 2006. Soil thaw and temperature response to air warming varies by plant community: Results from an open-top chamber experiment in northern Alaska. Arctic Antarctic Alpine Res. 38(2): 206-215. doi: 10.1657/1523-0430(2006)38[206:STATRT]2.0.CO;2.

Hollister, R.D., May, J.L., Kremers, K.S., Tweedie, C.E., Oberbauer, S.F., Liebig, J.A., et al. 2015. Warming experiments elucidate the drivers of observed directional changes in tundra vegetation. Ecol. Evol. 5(9): 1881-1895. doi: 10.1002/ ece3.1499.

Hoye, T.T., Post, E., Schmidt, N.M., Trojelsgaard, K., and Forchhammer, M.C. 2013. Shorter flowering seasons and declining abundance of flower visitors in a warmer Arctic. Nat. Clim. Change, 3(8): 759-763. doi: 10.1038/ NCLIMATE1909. 
Hudson, J.M.G., and Henry, G.H.R. 2009. Increased plant biomass in a high arctic heath community from 1981 to 2008. Ecology, 90(10): 2657-2663. doi: 10.1890/09-0102.1. PMID: 19886474.

IPCC. 2018. Global Warming of $1.5^{\circ} \mathrm{C}$ : Global Warming of $1.5^{\circ} \mathrm{C}$ : An IPCC Special Report on the Impacts of Global Warming of $1.5^{\circ} \mathrm{C}$ Above Pre-industrial Levels and Related Global Greenhouse Gas Emission Pathways, in the Context of Strengthening the Global Response to the Threat of Climate Change, Sustainable Development, and Efforts to Eradicate Poverty. Intergovernmental Panel on Climate Change.

Jia, G.J., Epstein, H.E., and Walker, D.A. 2009. Vegetation greening in the Canadian arctic related to decadal warming. J. Environ. Monit. 11(12): 2231-2238. doi: 10.1039/b911677j.

Johnson, D.R., Lara, M.J., Shaver, G.R., Batzli, G.O., Shaw, J.D., and Tweedie, C.E. 2011. Exclusion of brown lemmings reduces vascular plant cover and biomass in Arctic coastal tundra: resampling of a 50+ year herbivore exclosure experiment near Barrow, Alaska. Environ. Res. Lett. 6(4): 045507. doi: 10.1088/1748-9326/6/4/045507.

Joly, K., Jandt, R.R., and Klein, D.R. 2009. Decrease of lichens in Arctic ecosystems: the role of wildfire, caribou, reindeer, competition and climate in north-western Alaska. Polar Res. 28(3): 433-442. doi: 10.1111/j.17518369.2009.00113.x.

Jorgenson, J.C., Raynolds, M.K., Reynolds, J.H., and Benson, A. 2015. Twenty-five year record of changes in plant cover on tundra of northeastern Alaska. Arctic Antarctic Alpine Res. 47(4): 785-806. doi: 10.1657/AAAR0014-097.

Ju, J., and Masek, J.G. 2016. The vegetation greenness trend in Canada and US Alaska from 1984-2012 Landsat data. Remote Sens. Environ. 176: 1-16. doi: 10.1016/j.rse.2016.01.001.

Kaarlejarvi, E., Eskelinen, A., and Olofsson, J. 2017. Herbivores rescue diversity in warming tundra by modulating trait-dependent species losses and gains. Nat. Commun. 8: 419. doi: 10.1038/s41467-017-00554-z.

Knapp, A.K., and Seastedt, T.R. 1986. Detritus accumulation limits productivity of tallgrass prairie. Bioscience, 36(10): 662-668. doi: 10.2307/1310387.

Kobayashi, H., Nagai, S., Kim, Y., Yang, W., Ikeda, K., Ikawa, H., et al. 2018. In situ observations reveal how spectral reflectance responds to growing season phenology of an open evergreen forest in Alaska. Remote Sens. 10(7): 1071. doi: $10.3390 /$ rs10071071.

Kremers, K.S., Hollister, R.D., and Oberbauer, S.F. 2015. Diminished response of arctic plants to warming over time. PLoS ONE 10(3): e0116586. doi: 10.1371/journal.pone.0116586.

Lantz, T.C., Kokelj, S.V., Gergel, S.E., and Henryz, G.H.R. 2009. Relative impacts of disturbance and temperature: persistent changes in microenvironment and vegetation in retrogressive thaw slumps. Global Change Biol. 15(7): 1664-1675. doi: 10.1111/j.1365-2486.2009.01917.x.

Lara, M.J., Johnson, D.R., Andresen, C., Hollister, R.D., and Tweedie, C.E. 2017. Peak season carbon exchange shifts from a sink to a source following 50+ years of herbivore exclusion in an Arctic tundra ecosystem. J. Ecol. 105(1): 122-131. doi: 10.1111/1365-2745.12654.

Liu, Y., Miao, R., Chen, A., Miao, Y., Liu, Y., and Wu, X. 2017. Effects of nitrogen addition and mowing on reproductive phenology of three early-flowering forb species in a Tibetan alpine meadow. Ecol. Eng. 99: 119-125. doi: 10.1016/j.ecoleng.2016.11.033.

Liu, Y., Zhao, C., Guo, J., Zhang, L., Xuan, J., Chen, A., and You, C. 2021. Short-term phosphorus addition augments the effects of nitrogen addition on soil respiration in a typical steppe. Sci. Total Environ. 761: 143211. doi: 10.1016/ j.scitotenv.2020.143211.

Lokken, J.O., Evju, M., Soderstrom, L., and Hofgaard, A. 2020. Vegetation response to climate warming across the forest-tundra ecotone: species-dependent upward movement. J. Veg. Sci. 31(5): 854-866. doi: 10.1111/jvs.12911.

Lund, M., Hansen, B.U., Pedersen, S.H., Stiegler, C., and Tamstorf, M.P. 2014. Characteristics of summer-time energy exchange in a high Arctic tundra heath 2000-2010. Tellus, Ser. B 66: 21631. doi: 10.1111/jvs.12911.

May, J.L., and Hollister, R.D. 2012. Validation of a simplified point frame method to detect change in tundra vegetation. Polar Biol. 35(12): 1815-1823. doi: 10.1007/s00300-012-1224-1.

May, J.L., Parker, T., Unger, S., and Oberbauer, S.F. 2018. Short term changes in moisture content drive strong changes in Normalized Difference Vegetation Index and gross primary productivity in four Arctic moss communities. Remote Sens. Environ. 212: 114-120. doi: 10.1016/j.rse.2018.04.041.

McLaren, J.R., Buckeridge, K.M., van de Weg, M.J., Shaver, G.R., Schimel, J.P., and Gough, L. 2017. Shrub encroachment in Arctic tundra: Betula nana effects on above- and belowground litter decomposition. Ecology, 98(5): 1361-1376. doi: 10.1002/ecy.1790. PMID: 28263375.

Melillo, J.M., Steudler, P.A., Aber, J.D., Newkirk, K., Lux, H., Bowles, F.P., et al. 2002. Soil warming and carbon-cycle feedbacks to the climate system. Science, 298(5601): 2173-2176. doi: 10.1126/science.1074153. PMID: 12481133.

Miao, Y., Liu, M., Xuan, J., Xu, W., Wang, S., Miao, R., et al. 2020. Effects of warming on soil respiration during the non-growing seasons in a semiarid temperate steppe. J. Plant Ecol. 13(3): 288-294. doi: 10.1093/jpe/rtaa013.

Molau, U., and Mǿlgarrd, P. 1996. ITEX Manual. Danish Polar Center, Denmark.

Murray, D.F., and Murray, D.F. 1978. Checklists of vascular plants, bryophytes, and lichens from the Alaskan U.S. IBP Tundra Biome study areas - Barrow, Prudhoe Bay, Eagle Summit. In Vegetation and production ecology of an Alaskan Arctic Tundra. Edited by L.L. Tieszen. Springer-Verlag, New York. pp. 647-677.

Myers-Smith, I.H., Forbes, B.C., Wilmking, M., Hallinger, M., Lantz, T., Blok, D., et al. 2011. Shrub expansion in tundra ecosystems: dynamics, impacts and research priorities. Environ. Res. Lett. 6(4): 045509. doi: 10.1088/1748-9326/ 6/4/045509.

Myers-Smith, I.H., and Hik, D.S. 2018. Climate warming as a driver of tundra shrubline advance. J. Ecol. 106(2): 547-560. doi: 10.1111/1365-2745.12817. 
Myers-Smith, I.H., Grabowski, M.M., Thomas, H.J.D., Angers-Blondin, S., Daskalova, G.N., Bjorkman, A.D., et al. 2019. Eighteen years of ecological monitoring reveals multiple lines of evidence for tundra vegetation change. Ecol. Monogr. 89(2): e01351. doi: 10.1002/ecm.1351.

Myers-Smith, I.H., Kerby, J.T., Phoenix, G.K., Bjerke, J.W., Epstein, H.E., Assmann, J.J., et al. 2020. Complexity revealed in the greening of the Arctic. Nat. Clim. Change, 10(2): 106-117. doi: 10.1038/s41558-019-0688-1.

Natali, S.M., Schuur, E.A.G., and Rubin, R.L. 2012. Increased plant productivity in Alaskan tundra as a result of experimental warming of soil and permafrost. J. Ecol. 100(2): 488-498. doi: 10.1111/j.1365-2745.2011.01925.x.

Oberbauer, S.F., Starr, G., and Pop, E.W.1998. Effects of extended growing season and soil warming on carbon dioxide and methane exchange of tussock tundra in Alaska. J. Geophys. Res. Atmos. 103(D22): 29075-29082. doi: 10.1029/98JD00522.

Oberbauer, S.F., Elmendorf, S.C., Troxler, T.G., Hollister, R.D., Rocha, A.V., Bret-Harte, M.S., et al. 2013. Phenological response of tundra plants to background climate variation tested using the International Tundra Experiment. Philos. Trans. R. Soc. Lond. B. Biol. Sci. 368(1624): 20120481. doi: 10.1098/rstb.2012.0481.

Oksanen, J., Blanchet, F.G, Friendly, M., Kindt, R., Legendre, P., McGlinn, D., et al. 2019. vegan: Community Ecology Package. R package version 2.5-6. Available from https://CRAN-R-project.org/package=vegan.

Orians, G.H., and Wittenberger, J.F. 1991. Spatial and Temporal Scales in Habitat Selection. Am. Nat. 137: S29-S49. doi: $10.1086 / 285138$.

Parker, T.C., Sanderman, J., Holden, R.D., Blume-Werry, G., Sjoegersten, S., Large, D., et al. 2018. Exploring drivers of litter decomposition in a greening Arctic: results from a transplant experiment across a treeline. Ecology, 99(10): 2284-2294. doi: 10.1002/ecy.2442. PMID: 29981157.

Parker, T.C., Clemmensen, K.E., Friggens, N.L., Hartley, I.P., Johnson, D., Lindahl, B.D., et al. 2020. Rhizosphere allocation by canopy-forming species dominates soil $\mathrm{CO}_{2}$ efflux in a subarctic landscape. New Phytol. 227(6): 1818-1830. doi: 10.1111/nph.16573.

Pattison, R.R., Jorgenson, J.C., Raynolds, M.K., and Welker, J.M. 2015. Trends in NDVI and Tundra Community Composition in the Arctic of NE Alaska Between 1984 and 2009. Ecosystems, 18(4): 707-719. doi: 10.1007/s10021015-9858-9.

Phoenix, G.K., Gwynn-Jones, D., Callaghan, T.V., Sleep, D., and Lee, J.A. 2001. Effects of global change on a sub-Arctic heath: effects of enhanced UV-B radiation and increased summer precipitation. J. Ecol. 89(2): 256-267. doi: 10.1046/j.1365-2745.2001.00531.x.

Post, E., and Forchhammer, M.C. 2008. Climate change reduces reproductive success of an Arctic herbivore through trophic mismatch. Philos Trans. R Soc. Lond B. Biol. Sci. 363(1501): 2369-2375. doi: 10.1098/rstb.2007.2207.

Raynolds, M.K., Walker, D.A., and Maier, H.A. 2006. Alaska Arctic Tundra Vegetation. Alaska Geobotany Center, University of Alaska Fairbanks.

Raynolds, M.K., Walker, D.A., Verbyla, D., and Munger, C.A. 2013. Patterns of change within a tundra landscape: 22-year Landsat NDVI Trends in an Area of the Northern Foothills of the Brooks Range, Alaska. Arctic Antarctic Alpine Res. 45(2): 249-260. doi: 10.1657/1938-4246-45.2.249.

R Core Team. 2019. R: A Language and Environment for Statistical Computing, Vienna, Austria. Available from https://www.R-project.org/.

Rettie, W.J., and Messier, F. 2000. Hierarchical habitat selection by woodland caribou: its relationship to limiting factors. Ecography, 23(4): 466-478. doi: 10.1034/j.1600-0587.2000.230409.x.

Rustad, L.E., Campbell, J.L., Marion, G.M., Norby, R.J., Mitchell, M.J., Hartley, A.E., et al. 2001. A meta-analysis of the response of soil respiration, net nitrogen mineralization, and aboveground plant growth to experimental ecosystem warming. Oecologia, 126(4): 543-562. doi: 10.1007/s004420000544. PMID: 28547240.

Schuur, E.A.G., Crummer, K.G., Vogel, J.G., and Mack, M.C. 2007. Plant species composition and productivity following permafrost thaw and thermokarst in Alaskan tundra. Ecosystems, 10(2): 280-292. doi: 10.1007/s10021-007-9024-0.

Schuur, E.A.G., McGuire, A.D., Schaedel, C., Grosse, G., Harden, J.W., Hayes, D.J., et al. 2015. Climate change and the permafrost carbon feedback. Nature, 520(7546): 171-179. doi: 10.1038/nature14338. PMID: 25855454.

Shaver, G.R., Giblin, A.E., Nadelhoffer, K.J., Thieler, K.K., Downs, M.R., Laundre, J.A., and Rastetter, E.B. 2006. Carbon turnover in Alaskan tundra soils: effects of organic matter quality, temperature, moisture and fertilizer. J. Ecol. 94(4): 740-753. doi: 10.1111/j.1365-2745.2006.01139.x.

Stan Development Team. 2020. RStan: the R interface to Stan. R package version 2.19.3 Available from http://mcstan.org/.

Sundqvist, M.K., Moen, J., Bjork, R.G., Vowles, T., Kytoviita, M., Parsons, M.A., and Olofsson, J. 2019. Experimental evidence of the long-term effects of reindeer on Arctic vegetation greenness and species richness at a larger landscape scale. J. Ecol. 107(6): 2724-2736. doi: 10.1111/1365-2745.13201.

Tarnocai, C., Canadell, J.G., Schuur, E.A.G., Kuhry, P., Mazhitova, G., and Zimov, S. 2009. Soil organic carbon pools in the northern circumpolar permafrost region. Global Biogeochem. Cycles 23: GB2023. doi: 10.1029/2008GB003327.

van der Wal, R., and Stien, A. 2014. High-arctic plants like it hot: a long-term investigation of between-year variability in plant biomass. Ecology, 95(12): 3414-3427. doi: 10.1890/14-0533.1.

Villarreal, S., Hollister, R.D., Johnson, D.R., Lara, M.J., Webber, P.J., and Tweedie, C.E. 2012. Tundra vegetation change near Barrow, Alaska (1972-2010). Environ. Res. Lett. 7(1): 015508. doi: 10.1088/1748-9326/7/1/015508.

Vinton, M.A., and Burke, I.C. 1995. Interactions between individual plant-species and soil nutrient status in shortgrass steppe. Ecology, 76(4): 1116-1133. doi: 10.2307/1940920.

Walker, M.D. 1995. Patterns and causes of arctic plant community diversity. In Ecological Studies; Arctic and alpine biodiversity: Patterns, causes and ecosystem consequences, 113, pp. 3-20. 
Walker, M.D. 1996. Community baseline measurements for ITEX studies. Danish Polar Center, Copenhagen, Denmark.

Walker, M.D., Webber, P.J., Arnold, E.H., and Ebertmay, D. 1994. Effects of interannual climate variation on aboveground phytomass in alpine vegetation. Ecology, 75(2): 393-408. doi: 10.2307/1939543.

Walker, M.D., Wahren, C.H., Hollister, R.D., Henry, G., Ahlquist, L.E., Alatalo, J.M., et al. 2006. Plant community responses to experimental warming across the tundra biome. Proc. Natl. Acad. Sci. USA 103(5): 1342-1346. doi: 10.1073/pnas.0503198103.

Walther, G. 2010. Community and ecosystem responses to recent climate change. Philos. Trans. Biol. Sci. 365(1549): 2019-2024. doi: 10.1098/rstb.2010.0021.

Walther, S., Guanter, L., Heim, B., Jung, M., Duveiller, G., Wolanin, A., and Sachs, T. 2018. Assessing the dynamics of vegetation productivity in circumpolar regions with different satellite indicators of greenness and photosynthesis. Biogeosciences, 15(20): 6221-6256. doi: 10.5194/bg-15-6221-2018.

Zimov, S.A., Schuur, E.A.G., and Chapin, F.S. III. 2006. Permafrost and the global carbon budget. Science, 312(5780): 1612-1613. doi: 10.1126/science.1128908. PMID: 16778046. 